Original Contribution

\title{
RESISTANCE IN COMMON BEAN TO UROMYCES APPENDICULATUS UNDER FIELD AND GREENHOUSE CONDITIONS
}

\author{
M. Koleva ${ }^{1 *}$, Iv. Kiryakov ${ }^{2}$ \\ ${ }^{1}$ Bishop Konstantin Preslavski University of Shumen, College Dobrich, Bulgaria \\ ${ }^{2}$ Dobrudzha Agricultural Institute, General Toshevo, Bulgaria
}

\begin{abstract}
Bean rust, caused by Uromyces appendiculatus, is a major disease in common bean which occurs annually in The Rhodope Mountains and sporadic in the plains of Bulgaria. The present study aims to find sources of resistance in common bean to the pathogen for using in a breeding program. The reaction of fifty-five Phaseolus vulgaris accessions to the pathogen was monitored under field condition. Infection type, disease intensity and area under the disease progress curve were calculated. Twelve common bean cultivars were inoculated with eight pathotypes of races 20-2, 20-16, and 20-18 in the greenhouse, and infection type was estimated. Twelve accessions had an immune reaction, eight accessions had resistant a reaction, two accessions had a middle resistant reaction, and seven accessions had a susceptible reaction to $U$. appendiculatus population in both field estimations. Five cultivars showed resistant phenotype to the eight pathotypes in the greenhouse, four of which were resistant in the field (Abritus, Beslet, Trakiya, and Prelom). Five cultivars had a susceptible or resistant reaction to the pathotypes of the same race, resulting from different interaction between resistant genes in the host and virulent genes in the pathogen. Nine accessions showed race-nonspecific resistance in the field expressed in low disease intensity and susceptible/resistant phenotype.
\end{abstract}

Key words: Uromyces appendiculatus, Phaseolus vulgaris, race-specific resistance, race-nonspecific resistance

\section{INTRODUCTION}

The common bean (Phaseolus vulgaris L.) is the most widespread legume in Bulgaria. Although in the last two decades the fields with this crop have drastically decreased in the country, in the last few years there has been a tendency to increase them and they reached 1700 ha in 2019 (1). The yield of common beans is determined by some biotic factors, among which diseases are essential.

Bean rust is one of the most economically important diseases in common bean worldwide (2). It can cause yield losses up to $100 \%$ in years with favorable conditions (3). In Bulgaria, the disease was first reported in 1930 (4). It occurs annually in The Rhodope

\footnotetext{
*Correspondence to: Magdalena Koleva, Bishop Konstantin Preslavski University of Shumen, College Dobrich, m.koleva@shu.bg; 12 Dobrotitza, Dobrich, Bulgaria
}

mountains, where landraces of $P$. vulgaris and $P$. coccineus are grown (5). For the plains of the country, the disease is of sporadic importance, but in years with favorable conditions, it can spread epiphytotically (6-8).

The disease is caused by phytopathogenic fungus Uromyces appendiculatus (Pers.: Pers.) Unger. (3, 9). In Bulgaria, the pathogen overwinters as teliospores on plant debris in The Rhodope Mountains and spreads through urediniospores by wind in other parts of the country (5).

In most cases the resistance of $P$. vulgaris to $U$. appendiculatus is governed by a single dominant gene $(3,10)$ and less common by a single recessive gene (11), two epistatic genes (12), two independent and two complementary genes (13) or tightly linked genes (14). Fifteen race-specific genes are currently identified and listed in the bean genes list (15). The 
monogenic nature of common bean resistance to $U$. appendiculatus allows for the grouping of pathogen isolates into physiological races. Hundreds of races and pathotypes have been identified in different parts of the world (1619). In Bulgaria, 11 races of $U$. appendiculatus have been identified so far based on the reaction of the current rust differential set of 12 bean cultivars $(5,8,20)$. The latest study of the virulence diversity of the pathogen in Northeast Bulgaria found the spread of races $20-0,20-2,20-16$, and 20-18, the latter two being new to the country (20), but the reaction of the cultivars grown is unknown.

Breeding for disease resistance is the most economically effective and eco-friendly method for rust control in common bean (3, 17). The first step in every breeding program is to identify sources of resistance to the races of the pathogen distributed in a given area (21).

The present study aimed to find sources of resistance to $U$. appendiculatus for inclusion in a breeding program aimed at developing rustresistant bean cultivars.

\section{MATERIAL AND METHOD}

The investigation is carried out in Dobrudzha Agricultural Institute (DAI), General Toshevo during 2019-2020.

Field experiments. Fifty-five $P$. vulgaris accessions ( 15 cultivars, 28 lines, and 12 bean rust differentials) were sown in $1 \mathrm{~m}$ rows, 12 plants in a row. Every 10 accessions, one row of cultivar Dobrudzhanski 7 was sown as a susceptible check (standard). Perpendicular to the rows was sown cultivar Dobrudzhanski 7 as a spreader.

U. appendiculatus population collected in DAI in 2018 was used for inoculum. The spore mass was stored at $-18{ }^{\circ} \mathrm{C}$ in glass bottles with silica gel. Primary leaves of plants from the spreader were inoculated with spore suspension $\left(2 \times 10^{4}\right.$ spores $\left./ \mathrm{ml}\right)$ by rubbing with a paintbrush. After inoculation, the plants were covered by a dark moist chamber for $18 \mathrm{~h}$.

The disease reaction was estimated twice with an interval of 14 days. Six-degree scale was used for estimation infection type (IT), where 1 - no symptoms; 2 - necrotic spots without sporulation $(2-$ spots up to $0,3 \mathrm{~mm}$ in diameter; $2+$ - spots from 0,3 to $1,0 \mathrm{~mm}$ in diameter; $2++$-spots from 1,0 to $3,0 \mathrm{~mm}$ in diameter; $2+++$ - spots over $3,0 \mathrm{~mm}$ in diameter); 3 - uredinium up to $0,3 \mathrm{~mm}$ in diameter; 4 - uredinium from 0,3 to $0,5 \mathrm{~mm}$ in diameter; 5 - uredinium from 0,5 to $0,8 \mathrm{~mm}$ in diameter; 6 - uredinium over $0,8 \mathrm{~mm}$ in diameter (22). Disease intensity (DI) (percentage of leaf area infected) was estimated by using a modified Cobb scale (23). IT and DI are combined to obtain a final plant reaction classification on five categories: Immune, Resistant, Middle resistant, Susceptible, and Very susceptible according to Schoonhoven and Pastor-Corrales (Figure 1) (24).

\begin{tabular}{|c|c|c|c|c|c|c|c|}
\hline Immune & & & \multicolumn{5}{|c|}{ Resistant (R) } \\
\hline $2-1 \%$ & $2-5 \%$ & $2-10 \%$ & $2-15 \%$ & $2-30 \%$ & $2-40 \%$ & $2-65 \%$ & $2-100 \%$ \\
\hline $3-1 \%$ & $3-5 \%$ & $3-10 \%$ & $3-15 \%$ & $3-30 \%$ & $3-40 \%$ & $3-65 \%$ & $3-100 \%$ \\
\hline $4-1 \%$ & $4-5 \%$ & & & & & & \\
\hline $5-1 \%$ & $5-5 \%$ & & \multicolumn{5}{|c|}{ Middle resistant (MR) } \\
\hline \multirow[t]{5}{*}{$6-1 \%$} & $6-5 \%$ & & & & & & \\
\hline & & $\begin{array}{l}4-10 \% \\
5-10 \% \\
6-10 \%\end{array}$ & $4-15 \%$ & $4-30 \%$ & $4-40 \%$ & $4-65 \%$ & $4-100 \%$ \\
\hline & & & $5-15 \%$ & $5-30 \%$ & $5-40 \%$ & $5-65 \%$ & $5-100 \%$ \\
\hline & & & $6-15 \%$ & $6-30 \%$ & $6-40 \%$ & $6-65 \%$ & $6-100 \%$ \\
\hline & & & \multicolumn{4}{|c|}{ Susceptible (S) } & Very susceptible (VS) \\
\hline
\end{tabular}

*- IT-DI\%

Figure 1. Scale for estimation disease reaction to U. appendiculatus according to Infection Type (IT) and Disease Intensity (DI) under field condition 
DI was used for calculating Area Under Disease Progress Curve (AUDPC),

AUDPC $=\sum_{i=1}^{n-1}\left(\frac{x_{i}+x_{i+1}}{2}\right)\left(t_{i+1}-t_{i}\right)$

where $\mathrm{n}$ - number of estimations, $\mathrm{x}_{\mathrm{i}}-\mathrm{DI}, \mathrm{t}-$ days between the estimations. Relative AUDPC (rAUDPC) was calculated as a ratio between AUDPC of the accession and AUDPC of the next standard (stAUDPC) (25).

Greenhouse experiments. Twelve common bean cultivars, developed in DAI, were sown in plastic containers $(45 \times 30 \times 8 \mathrm{~cm})$ with peat mixture in 2020. Eight pathotypes of races 202, 20-16, and 20-18 of U. appendiculatus distributed in Northeast Bulgaria was used (20). They were labeled as P№/race, where P means pathotype. The pathotypes were stored as described above. The primary leaves of the plants were inoculated by rubbing spore suspension $\left(2 \times 10^{4}\right.$ spores $\left./ \mathrm{ml}\right)$ with a paintbrush then incubated in a moist chamber for $18 \mathrm{~h}(20$ ${ }^{\circ} \mathrm{C}$, humidity $>95 \%$ ). The plants were then grown at $20-25{ }^{\circ} \mathrm{C}$ (26). The virulent phenotype of the pathotypes was estimated 14 days after inoculation as IT using a six-degree scale described above. IT was recorded for both leaf surfaces. If more than one IT was found on the same plant, each IT was recorded in order of their frequency. IT-1 was
KOLEVA M., et al.

considering Immune reaction (I), IT-2 Hypersensitive reaction (HR), IT-3 Resistant reaction (R), IT-4,5,6 Susceptible reaction (S) (22).

\section{RESULTS AND DISCUSSION}

Field experiments. During the first estimation, the DI of the standard was from $10 \%$ to $70 \%$ and stAUDPC varies from 70 to 490 , with an average value 346.43 (data not shown). Among the twelve differential cultivars only Montcalm, Golden Gate Wax (GGW) (Ur- 6 ) and Compuesto Negro Chimaltenango (CNC) $(U r-C N C)$ had susceptible IT (IT-6) and low DI (from 1 to $5 \%$ ). When studying virulent potential of $U$. appendiculatus population under field conditions, the DI of differential cultivars is not taking into account. The IT of the cultivars provide information on which race-specific genes are overcome by the pathogen population, although the reaction of the cultivars, according to Schoonhoven and Pastor-Corrales scale is Resistant (Table 1). Fourteen accessions had immune reaction, 23 accessions resistant reaction, four middle resistant reactions, and 14 accessions had susceptible reaction to the pathogen during this estimation (Figure 2). The rAUDPC varied from 0.014 to 2.8 , except for the immune accessions with $\mathrm{rAUDCP}=0$.

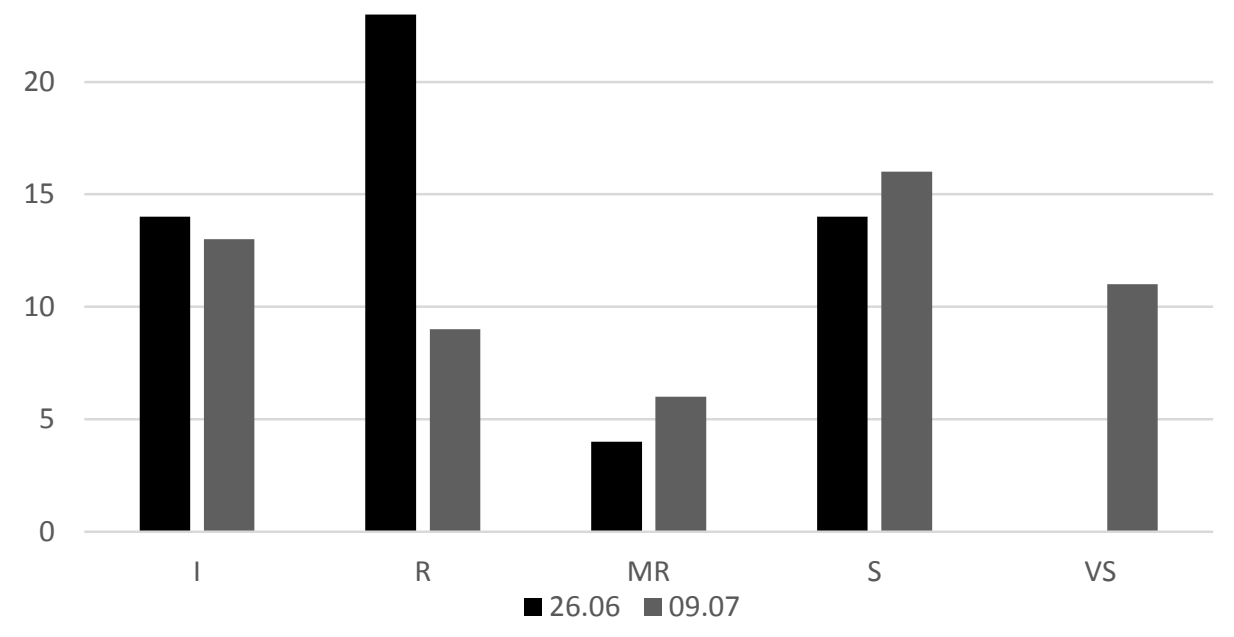

Figure 2. Reaction of 55 P. vulgaris accessions to U. appendiculatus under field condition during 2019

During the second estimation, standard DI was from $50 \%$ to $80 \%$ and stAUDPC varies from 525 to 1050 , with an average of 825 . The $U$. appendiculatus population overcomes racespecific genes $U r-4$ (Early Gallatin), $U r-6$ (GGW), $U r-C N C$ (CNC), and unidentified gene in cultivar Montcalm (Table 1). Thirteen accessions had immune phenotype, nine had resistant phenotype, six had middle resistant phenotype, and 16 had susceptible and 11 very susceptible phenotype to the pathogen (Figure 2). The rAUDPC varied from 0.025 to 2.267 , except for the immune accessions with rAUDCP $=0$. 
KOLEVA M., et al.

Table 1. Virulent potential of $U$. appendiculatus population on twelve bean rust differentials and disease reaction according to infection type and disease intensity of 55 common bean accessions under field condition in 2019

\begin{tabular}{|c|c|c|c|}
\hline Cultivar/Line & $U r$-genes & 28.06 & 09.07 \\
\hline Early Gallatin* & 4 & $\mathrm{R} * *(2 / 5 * * *)$ & $S(5 / 1)$ \\
\hline Redland Pioneer* & 13 & I $(1 / 0)$ & $\mathrm{I}(1 / 0)$ \\
\hline Montcalm* & - & $\mathrm{R}(6 / 5)$ & $S(6 / 50)$ \\
\hline Pompador Checa $50^{*}$ & $9 ; 12$ & $\mathrm{I}(1 / 0)$ & I (1/0) \\
\hline Golden Gate Wax* & 6 & $\mathrm{R}(6 / 5)$ & $S(6 / 50)$ \\
\hline PI 260418* & & $\mathrm{I}(1 / 0)$ & $\mathrm{I}(1 / 0)$ \\
\hline Great Northern $1140^{*}$ & 7 & $\mathrm{I}(1 / 0)$ & I $(1 / 0)$ \\
\hline Aurora* & 3 & $\mathrm{I}(1 / 0)$ & $\mathrm{I}(1 / 0)$ \\
\hline Mexico $309 *$ & 5 & $\mathrm{I}(1 / 0)$ & $\mathrm{I}(1 / 0)$ \\
\hline Mexico $235^{*}$ & & $\mathrm{I}(1 / 0)$ & $\mathrm{I}(1 / 0)$ \\
\hline Compuesto Negro Chimaltenango* & $U r-\mathrm{CNC}$ & $\mathrm{R}(6 / 5)$ & $\mathrm{R}(6 / 2)$ \\
\hline PI $181996^{*}$ & 11 & I & I \\
\hline Pukliv 2 & & $\mathrm{R}$ & $\mathrm{S}$ \\
\hline Skitiya & & S & VS \\
\hline Ustrem & & $\mathrm{R}$ & $\mathrm{R}$ \\
\hline Blyan & & S & VS \\
\hline Turnovo 13 & & I & I \\
\hline Abritus & & $\mathrm{R}$ & $\mathrm{R}$ \\
\hline Beslet & & I & I \\
\hline Dunav 1 & & I & I \\
\hline Trakiya & & $\mathrm{R}$ & I \\
\hline Prelom & & I & $\mathrm{R}$ \\
\hline Miziya & & $S$ & VS \\
\hline Elexir & & $S$ & $\mathrm{~S}$ \\
\hline Rodopeya & & I & MR \\
\hline Radoil & & S & $\mathrm{S}$ \\
\hline Zlatan & & I & I \\
\hline $9-11-1$ & & S & S \\
\hline $9-11-2$ & & $\mathrm{R}$ & $S$ \\
\hline $9-11-3$ & & MR & VS \\
\hline $9-11-4$ & & $\mathrm{R}$ & MR \\
\hline $9-11-5$ & & $S$ & $\mathrm{~S}$ \\
\hline $9-11-6$ & & $\mathrm{R}$ & $\mathrm{R}$ \\
\hline $12-11-18$ & & MR & VS \\
\hline $12-11-20$ & & MR & MR \\
\hline $12-12-3$ & & $\mathrm{R}$ & $\mathrm{R}$ \\
\hline $12-12-9$ & & $\mathrm{R}$ & $\mathrm{R}$ \\
\hline $13-6-2$ & & S & S \\
\hline $13-6-12$ & & $S$ & $S$ \\
\hline $13-12-7$ & & $\mathrm{~S}$ & $\mathrm{~S}$ \\
\hline $13-12-9$ & & $\mathrm{R}$ & S \\
\hline $13-12-21$ & & $\mathrm{R}$ & $S$ \\
\hline $13-12-22$ & & $\mathrm{R}$ & $\mathrm{S}$ \\
\hline $13-12-32$ & & $\mathrm{R}$ & VS \\
\hline $13-12-37$ & & $\mathrm{~S}$ & VS \\
\hline $13-21-15$ & & $\mathrm{R}$ & VS \\
\hline $13-35-2$ & & $\mathrm{~S}$ & VS \\
\hline $13-35-3$ & & MR & MR \\
\hline $13-35-20$ & & $\mathrm{R}$ & $\mathrm{S}$ \\
\hline $13-35-21$ & & $\mathrm{R}$ & VS \\
\hline $13-42-2$ & & $\mathrm{R}$ & MR \\
\hline $13-42-3$ & & $\mathrm{R}$ & MR \\
\hline $13-42-10$ & & $\mathrm{~S}$ & VS \\
\hline $13-42-11$ & & $\mathrm{R}$ & $\mathrm{R}$ \\
\hline $13-42-12$ & & $\mathrm{R}$ & $\mathrm{S}$ \\
\hline
\end{tabular}

*Differential cultivar

** I - immune; $\mathrm{R}$ - resistant; MR - middle resistant; $\mathrm{S}$ - susceptible; VS - very susceptible;

*** Infection type/Disease intensity (\%); 1 - immune; 2 - necrotic spots without sporulation up to $0,3 \mathrm{~mm}$ in diameter; 5 - uredinium from 0,5 to $0,8 \mathrm{~mm}$ in diameter; 6 - uredinium over $0,8 \mathrm{~mm}$ in diameter 
Twelve accessions had immune reaction, eight accessions had resistant reaction, two accessions had middle resistant reaction and seven accessions had susceptible reaction to $U$. appendiculatus population in both estimations. Among the immune cultivars were Turnovo 13, Beslet, Dunav 1, Zlatan, resistant were Ustrem and Abritus. The phenotype of others varies in different combinations. This variability can be explained by weather conditions and the virulent potential of $U$. appendiculatus population distributed in the field. It overcomes the race-specific genes $U r$ 6, $\mathrm{Ur}-\mathrm{CNC}$, and the gene in Montcalm in both estimations and $U r-4$ in the second estimation.

Under greenhouse conditions, Koleva and Kiryakov (20) isolated 17 single uredinium isolations from the same $U$. appendiculatus population, naturally occurring on cultivar Blyan and Skitiya in 2018. The virulent phenotype of the isolates to the rust differential set referred them to 16 pathotypes of races 20 $0,20-2,20-16$, and 20-18. These races overcome the race-specific genes $U r-6, U r-3$, $U r-C N C$ and unidentified gene in cultivar Montcalm in the differential set. Analysis of the virulence of the original $U$. appendiculatus population on the field shows that it contained more than four races, including a race which overcome gene $U r-4$ but that race probably had a low prevalence in the population and was not isolated in a greenhouse. The situation is similar with gene $U r-3$, present in cultivar Aurora and race 20-2. Koleva and Kiryakov (20) referred one isolate of the population to race 20-2, but in the field, in this investigation, cultivar Aurora had immune phenotype during both estimations. This probably is due to the low level of distribution of the race 20-2 in the field or lack of it.

Beleva (5) screened the resistance of $343 P$. vulgaris accessions to bean rust under field conditions during 2007-2008. Cultivar Eleksir was very susceptible, Abritus and Miziya had resistant to immune phenotype, Beslet and Trakiya were immune to bean rust during this period (5). In the present investigation, the phenotype of all these cultivars, except Miziya, is the same. Miziya was susceptible/very susceptible to bean rust in 2018 (Table 1), but during 2007-2008 the cultivar showed immune to resistant reaction. Comparative study between the virulence of $U$. appendiculatus populations in these two investigations showed higher virulence potential based on race- specific genes in the differential set during 2007-2008 (overcame genes $U r-6, U r-7, U r-3$, $U r-C N C, U r-8, U r-4, U r-6+$ and the gene in Montcalm) than in 2018 (Ur-6,Ur-4,Ur-CNC and the gene in Montcalm).

The results obtained from the field showed that the final estimation of the accessions is dependable on the virulent potential of the pathogen population, the race structure of the population, and the frequency of races in it. The resistance/susceptibility of the accessions is visible under greenhouse conditions against a set of races or pathotypes where the factor 'weather condition' is eliminated. In this case, greenhouse investigations give information about the interaction between race-specific gene in the cultivar and virulence gene in the pathogen, which is demonstrated only by IT.

Greenhouse experiments. Six cultivars had susceptible reaction to all eight pathotypes of $U$. appendiculatus included in this investigation (Table 2). Under field conditions, Blyan, Eleksir, Skitya, Miziya, and Radoil had susceptible phenotype, but Zlatan had immune reaction.

Cultivars Pukliv 2, Abritus, Beslet, Trakiya, and Prelom had immune, hypersensitive, or resistant reaction to the pathotypes of $U$. appendiculatus (Table 2). They had immune to resistant phenotype under field condition, except Pukliv 2 who had susceptible phenotype. The differences in disease reaction of cultivars Zlatan and Pukliv 2 can be explained again by the virulence potential and race structure of the original $U$. appendiculatus population.

Cultivar Ustrem had resistant phenotype to two pathotypes of race 20-18 and susceptible phenotype to the rest two pathotypes of the same race (Table 2). The cultivar showed completely different reactions (from immune to susceptible) to the three pathotypes of race 20-16. A similar situation in the pathotypes of a race can be observed in cultivars Pukliv 2, Abritus, Trakiya, Prelom (Table 2). The results from this investigation confirm the position of Parlevliet (27) that the term 'race' is a conditional concept whose designation is highly dependable by the race-specific genes in the differential set. According to the University of Cornell (28), the race is a subspecies group of pathogens that infect a given set of plant 
KOLEVA M., et al.

cultivars and pathotype is an infrasubspecific classification of a pathogen distinguished from others of the species by its pathogenicity on a specific host or race is a qualitative concept and the pathotype is a quantitative concept.
The different IT of a cultivar after inoculation with pathotypes of a race is a result of different interactions between the resistant genes in the host and virulent genes in the pathogen.

Table 2. Reaction of twelve common bean cultivars to eight pathotypes referred races 20-2, 20-16 and 20-18 of U. appendiculatus in greenhouse conditions

\begin{tabular}{|c|c|c|c|c|c|c|c|c|}
\hline $\begin{array}{l}\text { Cultivar/ } \\
\text { Pathotype }\end{array}$ & $\begin{array}{l}\stackrel{\tilde{丶}}{S} \\
\text { a }\end{array}$ & 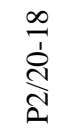 & $\frac{\infty}{\frac{\infty}{1}}$ & 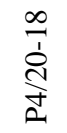 & $\frac{\infty}{\frac{1}{d}}$ & 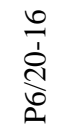 & 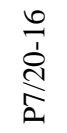 & $\begin{array}{l}0 \\
\frac{1}{1} \\
\stackrel{\mathbb{1}}{\infty} \\
\stackrel{0}{\alpha}\end{array}$ \\
\hline Pukliv 2 & $\mathrm{HR}^{*}$ & HR & $\mathrm{HR}$ & $\mathrm{R}$ & $\mathrm{R}$ & HR & $\mathrm{HR}$ & $\mathrm{R}$ \\
\hline Skitiya & $\mathrm{S}$ & $\mathrm{S}$ & $S$ & $S$ & $S$ & $\mathrm{~S}$ & S & $S$ \\
\hline Ustrem & $\mathrm{R}$ & $\mathrm{R}$ & $S$ & $S$ & $\mathrm{R}$ & $S$ & I & $\mathrm{R}$ \\
\hline Blyan & $S$ & $S$ & S & $S$ & $S$ & $S$ & $S$ & $S$ \\
\hline Abritus & $\mathrm{R}$ & I & I & $\mathrm{R}$ & $\mathrm{R}$ & I & I & I \\
\hline Beslet & HR & I & I & I & I & I & I & I \\
\hline Trakiya & HR & HR & I & HR & HR & HR & HR & HR \\
\hline Prelom & HR & HR & I & HR & $\mathrm{R}$ & HR & I & HR \\
\hline Miziya & $\mathrm{S}$ & $\mathrm{S}$ & $\mathrm{S}$ & $\mathrm{S}$ & $S$ & $\mathrm{~S}$ & $S$ & $\mathrm{~S}$ \\
\hline Eleksir & $S$ & $S$ & $S$ & S & $S$ & S & $S$ & $S$ \\
\hline Radoil & S & S & S & S & S & S & S & S \\
\hline Zlatan & $\mathrm{S}$ & $\mathrm{S}$ & $\mathrm{S}$ & $\mathrm{S}$ & $\mathrm{S}$ & $\mathrm{S}$ & $\mathrm{S}$ & $\mathrm{S}$ \\
\hline
\end{tabular}

*I - immune; HR - hypersensitive; R - resistant; S - susceptible

This investigation showed that four common bean cultivars (Abritus, Beslet, Trakiya, and Prelom), developed in DAI, were resistant to bean rust under field conditions and had immune, hypersensitive or resistant phenotype to eight pathotypes of races $20-2,20-16$, and 20-18 of $U$. appendiculatus, distributed in Northeast Bulgaria. These cultivars can be successfully used as a donor parent in a breeding program for high productive common bean cultivars resistant to bean rust.

Previous investigations about sources of resistance to six pathotypes of races 20-0, 20$3,20-19,29-0,29-1$ and $52-3$ of $U$. appendiculatus in Bulgaria showed that Abritus was resistant to the pathotypes of races 29-0 and 20-19 and Trakiya was immune to the pathotypes of 20-19 and 20-3 and had hypersensitive reaction to the pathotypes of 200, 20-1, 20-2, and 52-3 (5, 29). Cultivar Beslet had immune to resistant reaction to all 90 pathotypes of nine races $(20-0,20-1,20-2,20-$ $3,20-19,52-3,29-0,29-1,28-1)$ identified by Beleva (2010). Cultivar Prelom had susceptible phenotype to a pathotype of races 29-1, 20-3, and 52-3.

Results of present and previous studies showed that cultivar Trakiya has immune phenotype to pathotypes of races 20-19, 20-18, 20-3, hypersensitive reaction to the pathotypes of 20$0,20-1,20-2,20-16,20-18$, and 52-3 and susceptible phenotype to the pathotypes of races 29-0 and 29-1. Compared by the rest, races $29-0$ and 29-1 are the only ones that overcome race-specific genes $U r-4$ (Early Gallatin) and Ur-9, Ur-12 (Pompadour Checa 50). Pastor-Corrales and Stavely (30) proposed a method for identifying race-specific genes using a set of races. Using races $47,53,67$, and 49, the authors identified genes $U r-6, U r-3$, $U r-11$, and combination between $U r-4$ and $U r$ 11. Following this method is possible to suppose that cultivar Trakiya has a combination of race-specific genes $U r-4$ and $U r-9$ (Ur-12 govern adult plant resistance) but additional investigations have to be made to confirm or reject this supposal. 
Developing cultivars with race-specific (vertical) resistance hide a risk of appearance of new, highly virulent races/pathotypes which break down the resistance $(3,17)$. Despite multiple evidences of the monogenetic character of the resistance of $P$. vulgaris to $U$. appendiculatus, there are some research works about race-nonspecific (horizontal) resistance. According to Habtu and Zadoks (31) cultivars with race-nonspecific resistance showed a long latent period, low infection efficacy, low sporulation capacity, low infection period, and small size pustules. Under field conditions, it is possible to estimate only infection efficacy, expressed by DI, and pustule size, expressed by IT. Beleva (5) identified $41 P$. vulgaris accessions with race-nonspecific resistance to $U$. appendiculatus during 2007-2008. They showed rAUDPC 0.091-0.333 in 2007 and $0.059-0.353$ in 2008 . The IT of the accessions were susceptible (IT-4,5,6), except cultivar VAX4 and VAX 6 with IT-3.
In this investigation, nine accessions showed low DI, from 1 to $10 \%$, and susceptible phenotype (IT-4,5,6), except cultivar Ustrem in the field (Table 3). The final plant reaction of these accessions according to Schoonhoven and Pastor-Corrales is Resistant/Middle resistant (Table 1). The rAUDPC varied from 0.014 (Ustrem) to 0.2 (lines 13-42-2 and 13$42-3)$ in the first estimation and from 0.025 (Ustrem) to 0.143 (line 12-11-20) in the second. Cultivar Ustrem showed IT-3 during the two estimations (Table 3) which is considered a resistant phenotype (22). The reactions of Ustrem and Abritus under the greenhouse condition (Table 2) demonstrate that the cultivars have a race-specific gene for resistance to bean rust. Similar results were observed by Beleva (5) with cultivars VAX4 and VAX 6. This confirms the view of some authors that race-nonspecific resistance can be race/isolate-specific (5, 32). Additional investigations have to be made to confirm or reject the results obtained about racenonspecific resistance of the accessions.

Table 3. Infection type (IT), Disease intensity (DI) and relative Area Under Disease Progress Curve (rAUDPC) of nine P. vulgaris accessions under field condition in 2019

\begin{tabular}{|l|ccccccccc|}
\hline \multirow{2}{*}{ Accession } & \multicolumn{4}{|c|}{28.06} & \multicolumn{4}{c|}{09.07} \\
\cline { 2 - 9 } & IT & DI & stAUDPC & rAUDPC & IT & DI & stAUDPC & rAUDPC \\
\hline Ustrem & $4,3 / 5^{*}$ & $1^{* *}$ & 490 & 0,014 & $3,4 / 4,5$ & 2 & 840 & 0,025 \\
Abritus & $4,3 / 4,3,5$ & 1 & 490 & 0,014 & $5,6,4 / 6,5$ & 5 & 840 & 0,050 \\
$9-11-4$ & $5 / 5,6$ & 2 & 350 & 0,040 & $6 / 6$ & 10 & 910 & 0,092 \\
$12-11-20$ & $6 / 6$ & 10 & 490 & 0,143 & $6,5 / 6,5$ & 10 & 980 & 0,143 \\
$12-12-3$ & $6 / 6$ & 5 & 490 & 0,071 & $6 / 4$ & 2 & 980 & 0,050 \\
$12-12-9$ & $6 / 6$ & 5 & 490 & 0,071 & $6,5 / 6,5,4$ & 5 & 980 & 0,071 \\
$13-42-2$ & $6 / 6$ & 2 & 70 & 0,200 & $5,4 / 5$ & 10 & 630 & 0,133 \\
$13-42-3$ & $6 / 6$ & 2 & 70 & 0,200 & $6 / 6$ & 10 & 630 & 0,133 \\
$13-42-11$ & $6,5 / 6,5$ & 1 & 490 & 0,014 & $4 / 4,5$ & 2 & 1050 & 0,020 \\
\hline
\end{tabular}

* abaxial/adaxial leaf surface, where 3 - uredinium up to $0,3 \mathrm{~mm}$ in diameter; 4 - uredinium from 0,3 to $0,5 \mathrm{~mm}$ in diameter; 5 - uredinium from 0,5 to $0,8 \mathrm{~mm}$ in diameter; 6 - uredinium over $0,8 \mathrm{~mm}$ in diameter ** percentage of leaf area infected

\section{CONCLUSSIONS}

Twelve $P$. vulgaris accessions had immune reaction, eight accessions had resistant reaction, two accessions had middle resistant reaction to $U$. appendiculatus under field condition in 2019.

Cultivars Pukliv 2, Abritus, Beslet, Trakiya, and Prelom had immune, hypersensitive or resistant reaction to eight pathotypes of races
20-2, 20-16 and 20-18 of U. appendiculatus under greenhouse conditions.

Cultivars Abritus, Beslet, Trakiya, and Prelom developed in DAI were resistant to $U$. appendiculatus under field conditions and had immune, hypersensitive or resistant phenotype to eight pathotypes of races $20-2,20-16$ and 20-18 of the pathogens, distributed in Northeast Bulgaria, and can be successfully used as a donor parent in a breeding program 
for high productive common bean cultivars resistant to bean rust.

Nine accessions showed race-nonspecific resistance expressed in low disease intensity and susceptible or resistant phenotype under field conditions.

\section{REFERENCES}

1. Ministry of Agriculture, Food and Forestry. Operational analysis for basic crops, 2019. https://www.mzh.government.bg/media/file r_public/2019/08/21/operativen_analiz_201 9-08-21_Xrho2QO.pdf.

2. Liebenberg, M. M., Pretorius, Z. A., Common Bean Rust: Pathology and Control. Horticultural Reviews, 37:1-99, 2010.

3. Stavely, J. R., Pastor-Corrales, M. A., Rust. In: Schwartz, H. F., Pastor-Corrales M. A., eds. Bean production problems in the tropics. CIAT, Cali, Colombia. pp. 159194, 1989.

4. Kovachevski, I., The diseases in common bean. Sofia: National Printing House, pp. 43-44, 1930.

5. Beleva, M., Investigations on common bean rust in Bulgaria. PhD Thesis, General Toshevo, Dobrudzha Agricultural Institute, 2010.

6. Kiryakov, I., Genchev, D., Physiological specialization of Uromyces appendiculatus (Pers.: Pers.) Unger. in Bulgaria and sources of resistance. Research communications of USB branch Dobrich, 3:45-50, 2001.

7. Kiryakov, I., Genchev, D., Races of bean rust in Northeastern of Bulgaria during 2002. Research communications of USB branch Dobrich, 5(1):72-76, 2003.

8. Kiryakov, I., Genchev, D., New sources of resistance to bean rust in the collection of Dobroudja Agricultural Institute. Research communications of USB branch Dobrich, 6(1):72-77, 2004.

9. Harter, L. L., Zaumeyer, W. J., Differentiation of physiologic races of Uromyces phaseoli typical on bean. Journal of Agricultural Research, 62(12):717-731, 1941.

10.Pastor-Corrales, M. A., Inheritance of resistance in PI 260418 an Andean bean resistant to most races of bean rust pathogen. Annual Report of Bean Improvement Cooperative, 48:134-135, 2005.
11.Zaiter, H. Z., Coyne, D. P. and Steadman J. R., Inheritance of resistance to a rust isolate in beans. Annual Report of Bean Improvement Cooperative, 32:126-127, 1989.

12.Finke, M. L., Coyne, D. P. and Steadman, J. R., The inheritance and association of resistance to rust, common bacterial blight, plant habit and foliar abnormalities in Phaseolus vulgaris L. Euphytica, 35:969982, 1986.

13.Grafton, K. F., Weiser, G. C., Littlefield, L. J. and Stavely, R. J., Inheritance of resistance to two races of leaf rust in dry edible bean. Crop Science, 25:537-539, 1985.

14.Park, S. P., Coyne, D. P., Bokosi, J. M. and Steadman, J. R., Molecular markers linked to genes for specific resistance and indeterminate growth habit in common bean. Euphytica, 150:133-141, 1999.

15.Bean Improvement Cooperative, Bean Genes List, 2020. http://www.bic.uprm.edu/wpcontent/uploads/2019/10/Bean-Genes-List2018-v2-1.pdf

16.Avecedo, M., Steadman, J. R., Rosas, J. C., Venegas, J., Coevolution of the bean rust pathogen Uromyces appendiculatus with its wild, weedy and domesticated hosts (Phaseolus spp.) at a center of diversity. Annual Report of Bean Improvement Cooperative, 51:22-23, 2008.

17.Avecedo, M., Steadman, J. R., Rosas, J. C., Uromyces appendiculatus in Honduras: Pathogen diversity and host resistance screening. Plant Disease, 97(5):652-661, 2013.

18.Paucar, B., Murillo, A., Falconi, E., Peralta, E., Pathogenic variability of Uromyces appendiculatus in bean production areas in Northern Ecuador. Annual Report of Bean Improvement Cooperative, 49:231-232, 2006.

19.Souza, T. L. P. O., Ragagnin, V. A., Sanglard, D. A., Moreira, M. A., Barros, E. G., Identification of races of selected isolates of Uromyces appendiculatus from Minas Gerais (Brazil) based of the new International classification system. Fitopatologia Brasileira, 32(2):104-109, 2007.

20.Koleva, M., Kiryakov, I., Pathotype diversity of Uromyces appendiculatus in Northeastern Bulgaria. Journal of Central 
European Agriculture, 21(4):789-795, 2020.

21.Sillero, J. C., Fondevilla, S., Davidson, J., Vaz Patto, M. C., Warkentin, T. D., Thomas, J. and Rubiales, D., Screening techniques and sources of resistance to rusts and mildews in grain legumes. Euphytica, 147:255-272, 2006.

22.Stavely, J. R., Freytag, G. F., Steadman, J. R., Schwartz, H. F., The 1983 Bean Rust Workshop. Annual Report of Bean Improvement Cooperative, 26, iv-vi, 1983.

23.Stavely, J. R., The modified Cobb scale for estimating bean rust intensity. Annual Report of Bean Improvement Cooperative, 28:31-32, 1985.

24.Schoonhoven, A. and Pastor-Corrales, M. A., Standard system for the evaluation of bean germplasm. Centro Internacional de Agricultura Tropical, Cali, Colombia, 1987.

25.Li, Z. F., Xia, X. C., Zhou, X. C., Niu, Y. C., He, Z. H., Zhang, Y., Li, G. Q., Wan, A. M., Wang, D. S., Chen, X. M., Lu, Q. L. and Singh, R. P., Seedling and slow rusting resistance to stripe rust in chinese common wheats. Plant Disease, 90:1302-1312, 2006.

26.Stavely, J. R., A rapid technique for inoculation of Phaseolus vulgaris with multiple pathotypes of Uromyces phaseoli. Phytopathology, 73(5): 676-679, 1983.
27.Parlevliet, J. E., Race and pathotype concepts in parasitic fungi. Bulletin OEPP, 15(2):145-150, 1985.

28.Cornell University, On-Line Glossary of Technical Terms in Plant Pathology, 2020. http://www.plantpath.cornell.edu/glossary/ Glossary.htm

29.Genchev, D., Kiryakov, I., Beleva, M., 'Trakia' - A New Dry Bean variety (Phaseolus vulgaris L.) Field Crop Studies, 7(1):83-94, 2011.

30.Pastor-Corrales, M. A. and Stavely, J. R., Using specific races of the common bean rust pathogen to detect resistance genes in Phaseolus vulgaris. Annual Report of Bean Improvement Cooperative, 45:78-79, 2002.

31.Habtu, A. and Zadoks, J. C., Components of partial resistance in phaseolus beans against an Ethiopian isolate of bean rust. Euphytica, 83:95-102, 1995.

32.Geffroy, V., Sėvignac, M., De Oliveira, J. C. F., Fouilloux, G., Skroch, P., Thoquet, P., Gepts, P., Langin, T. and Dron, M., Inheritance of partial resistance agains Colletotrichum lindemuthianum in Phaseolus vulgaris and co-localization of quantitative trait loci with genes involved in specific resistance. Molecular PlantMicrobe Interactions, 13(3):287-296, 2000. 